\title{
Forecast and impact of electromobility development on the Polish Electric Power System
}

\author{
Mariusz Kłos ${ }^{1}$, Piotr Marchel $^{1}$, Józef Paska ${ }^{1,}{ }^{*}$, Rafat Bielas ${ }^{1}$, Magdalena Błędzińska ${ }^{1}$, \\ Łukasz Michalski ${ }^{1}$, Konrad Wróblewski ${ }^{1}$, and Krzysztof Zagrajek ${ }^{1}$ \\ ${ }^{1}$ Warsaw University of Technology, Institute of Electrical Power Engineering, ul. Koszykowa 75, \\ Gmach Mechaniki, Warszawa, Poland
}

\begin{abstract}
Thanks to the development of technology, the presence of electric vehicles (EVs) on the roads is no longer a purely theoretical issue. Also in Poland, electric cars are already visible on the streets, and charging stations (EVCS) are increasingly being installed near newly emerging buildings and housing estates. The article attempts to determine to what extent the use of electric cars will affect the demand for power and energy in the Polish electric power system (PEPS). The basis for PEPS modernization plans should be a detailed analysis of the technical adequacy of all its subsystems: generation, transmission and distribution, on the basis of which it will be possible to assess the potential impact of EVCS infrastructure operation on the Polish electric power system. This publication presents an example of such analysis for the distribution subsector, most exposed to potential negative interactions with the future, extensive infrastructure of EVCS.
\end{abstract}

\section{Introduction}

The popularisation of battery electric (BEV) and hybrid cars (PHEV) is currently one of the challenges that power systems have to face. The increase in the number of electric cars may be defined as cumulative, as it will be facilitated by: legal regulations promoting electric transport, reduction of vehicle prices resulting from technological development and mass production. It should be expected that in the perspective of several decades the electric cars will be the dominant in field of private transport, and in a dozen or so years the share of cars powered by electric energy will be much more significant than today.

The amount of power demand and its variability, with the current and forecasted conditions for the development of generation infrastructure (including the share of each power generation technologies) and the National Power System (NPS) network, are the main determinants of the stability and reliability of the national power system, and therefore the level of security of electricity supply.

\footnotetext{
${ }^{*}$ Corresponding author: jozef.paska@ien.pw.edu.pl
} 
Thanks to technological developments, the presence of electric vehicles (EV) on the roads is no longer a purely theoretical issue. In Poland, electric cars are already visible on the streets, and charging stations (EVCS) are increasingly being installed near newly constructed buildings and housing estates. The electric vehicle is no longer seen as a technical innovation. Looking at the global electromobility market in technical and formal terms, a clear trend can be observed, according to which the development of electromobility will be very dynamic in the next decade [1-2]. As the electric vehicles and charging stations sector is only in its infancy, it is attractive to potential investors. In Poland, the process of modernisation and development of the automotive transport sector, which is going to be mostly based on electric vehicles, has also accelerated [3]. In such a dynamic situation, it is necessary to develop and consistently implement a long-term strategy for the modernisation and development of the NPS, which is crucial for the national economy and will have a bearing on the pace of introduction of the electric vehicle fleet in Poland. The basis for NPS modernisation plans should be a detailed analysis of technical adequacy of all its sub-sectors: generation, transmission and distribution, on the basis of which it will be possible to assess the potential impact of the operation of the EVCS infrastructure on NPS.

\section{Forecast of the development of electromobility in Poland}

The Electromobility Development Plan [4] presented by the Ministry of Energy estimates that the number of electric cars will reach one million in 2025. This article will present a forecast of the development of electromobility in the country. In many years of thorough observations, in which the method of popularisation of new technological solutions was studied, it was noted that these solutions are implemented in accordance with the logistic function, which is given by the following formula [5-6].

$$
y(t)=\frac{a}{1+b \cdot e^{-c \cdot t}},
$$

where $a>0, b>1, c>0$ are the function parameters. Parameter $a$ corresponds to the saturation level (logistic function asymptotically strives for $a$ ).

A logistic function describes population growth assuming resource constraints. In the case of the popularisation of devices and technologies, such a limit is reached by getting to market saturation. In such a situation, all those, who are interested in given product, own it or it might occurred that certain product ceases to satisfy the needs of consumers. In the case of technology, four life phases of the product can be determined [7-8]: I - entry of the product to the market, II - increase in sales of the product, III - maturity and saturation of the market, IV - decrease in sales of the product and exit from the market.

Table 1 presents a forecast of the development of electromobility in Poland in the years 2017-2040. A population $\left(L_{t}\right)$ was adopted on the basis of the population forecast for the years 2014-2050 prepared in 2014 by the Central Statistical Office [9]. 
Table 1. Projected population, no. of cars and electric cars in Poland in 2017-2040

(* - statistics data [2-5]).

\begin{tabular}{|c|c|c|c|c|c|}
\hline $\begin{array}{c}\text { Year } \\
\boldsymbol{t}\end{array}$ & $\begin{array}{c}\text { Population } \\
\boldsymbol{L}_{\boldsymbol{t}}\left[\mathbf{1 0}^{\mathbf{6}}\right]\end{array}$ & $\begin{array}{c}\text { No. of cars/1000 } \\
\text { inhab. } \boldsymbol{w s}_{\boldsymbol{t}}\end{array}$ & $\begin{array}{c}\text { No. of cars } \\
\boldsymbol{S}_{\boldsymbol{t}}\left[\mathbf{1 0}^{\mathbf{3}}\right]\end{array}$ & $\begin{array}{c}\text { Share of electric } \\
\text { cars } \boldsymbol{u} \boldsymbol{e}_{\boldsymbol{t}}\end{array}$ & $\begin{array}{c}\text { No. of EV } \\
\boldsymbol{E}_{\boldsymbol{t}}\left[\mathbf{1 0}^{\mathbf{3}} \boldsymbol{]}\right.\end{array}$ \\
\hline 2015 & $38399^{*}$ & $539.2^{*}$ & $20933^{*}$ & $0.01 \%$ & 2.03 \\
\hline 2018 & 38285 & 601.0 & 23012 & $0.09 \%$ & 20.42 \\
\hline 2020 & 38138 & 636.6 & 24278 & $0.39 \%$ & 94.00 \\
\hline 2025 & 37741 & 715.7 & 27011 & $13.47 \%$ & 3637 \\
\hline 2030 & 37185 & 779.0 & 28968 & $86.17 \%$ & 24962 \\
\hline 2035 & 36477 & 826.9 & 30164 & $99.60 \%$ & 30044 \\
\hline 2040 & 35668 & 861.6 & 30732 & $99.99 \%$ & 30729 \\
\hline
\end{tabular}

On the basis of historical data [10-12] the parameters of the logistic function were determined using the Hotelling method (described in [5]). Assuming that 1990 was the zero year, the following estimators of logistic function parameters were obtained: $a=935.9$ [cars $/ 1000$ inhabitants], $b=5.9855, c=0.0848$. Based on equation (1) the value of the coefficient in the years 2018-2040 was estimated as it is shown in formula (2).

$$
w s_{t}=\frac{935,9}{1+5,9855 \cdot e^{-0,0848 \cdot t}},
$$

where: $t$ - year number, assuming 1990 is the zero year.

An estimate of the initial number of electric cars $\left(E_{\text {est }}\right)$ in the early years was based on available statistics [10-12] for the period 2014-2016, which was assumed to be the first phase of product development when growth was not restricted. The growth rate of the number of cars (ratio of the number of cars in a given year to the number in the previous year) was assumed to be 1.85 (average from 2014-2016). On the basis of this estimate of the number of electric cars, the share of electric cars $\left(u e_{t}\right)$ in the period 2014-2025 was determined. For this coefficient, the parameters of the logistic function describing it (assuming 2015 as 0 ) were estimated: $a=100 \%, b=10302, c=0.7380$. Based on formula (1), the share of electric cars in the years 2015-2040 was estimated from formula (3).

$$
u e_{t}=\frac{100 \%}{1+10302 \cdot e^{-0,7380 \cdot t}},
$$

where: $t$-year number, assuming 2015 is the zero year.

The final forecast of the number of electric cars in year $t$ was determined by the relation (4).

$$
E_{t}=u e_{t} \cdot L_{t} .
$$

The results of the forecast indicate that the number of one million electric cars may actually be achieved around 2024, however, it should be remembered that the values obtained are indicative. The speed of development of electromobility depends on many factors like the legal and economic environment. An appropriate laws and programmes may both speed up its development or contribute to its halting. The development of the technology itself will have a major impact - the 
more popular it is, the lower the unit costs are. The forecast does not take into account changes in fuel and electricity prices. The increase in the number of electric vehicles and the associated increase in demand for power and energy may increase the price of electricity. The decreasing share of combustion vehicles in the world may reduce price of liquid fuels, as a result of which the costs of driving an electric car may approach the price of driving an combustion engine vehicle. However, the presented forecast is feasible and it is expected that from 2020 onwards, there will be an almost complete shift from current means of transport to fully electric vehicles over a period of about 15-20 years. This enormous challenge should be already taken into account while planning the development of the National Power System.

\section{Forecast of growth in demand for energy in Polish NPS}

Electricity demand in a car depends on a number of factors: driving style, ambient temperature or the use of additional energy devices. On the basis of the available catalogue data and studies [13-14], it can be assumed that the average energy consumption of an electric car is approximately equal to $200 \mathrm{Wh} / \mathrm{km}$. The traffic growth forecast for passenger cars $\left(R_{t}\right)$ has been made using the extrapolation method from linear regression for historical data from years 2008-2015 [11]. The average annual mileage of passenger cars $\left(D_{t}\right)$ was determined on the basis of formula (5).

$$
D_{t}=R_{t} / S_{t}, \text { in } \mathrm{km} / \mathrm{a} .
$$

Using the forecasted number of electric cars, the traffic generated by electric cars $E_{t}$ was estimated from the formula:

$$
R E_{t}=E_{t} \cdot D_{t}, \text { in } \mathrm{km} / \mathrm{a} .
$$

Taking into account the average energy consumption $Z_{\text {sam }}=200 \mathrm{Wh} / \mathrm{km}$, the forecasted annual energy demand of electric cars was determined:

$$
A_{t}=R E_{t} \cdot Z_{\text {sam }}, \text { in } \mathrm{Wh} / \mathrm{a} .
$$

The obtained forecast results for the years 2020-2040 are presented in Table 2.

Table 2. Projected energy demand of electric passenger cars in Poland in the years 2020-2040.

\begin{tabular}{|c|c|c|c|c|c|}
\hline $\begin{array}{c}\text { Year } \\
\boldsymbol{t}\end{array}$ & $\begin{array}{c}\text { Total } \\
\text { mileage } \boldsymbol{R}_{\boldsymbol{t}} \\
{\left[\mathbf{1 0}^{\mathbf{6}} \mathbf{~ k m}\right]}\end{array}$ & $\begin{array}{c}\text { Average } \\
\text { annual mileage } \\
(\mathbf{E V}) \boldsymbol{D}_{\boldsymbol{t}}[\mathbf{k m} / \mathbf{a}]\end{array}$ & $\begin{array}{c}\text { No. of EV } \boldsymbol{E}_{\boldsymbol{t}} \\
{\left[\mathbf{1 0}^{\mathbf{3}}\right]}\end{array}$ & $\begin{array}{c}\text { Total mileage } \\
(\mathbf{E V}) \boldsymbol{R E}_{\boldsymbol{t}} \\
{\left[\mathbf{1 0}^{\mathbf{6}} \mathbf{~ k m}\right]}\end{array}$ & $\begin{array}{c}\text { Annual demand } \\
\text { of electric energy } \\
\boldsymbol{A}_{\boldsymbol{t}}[\mathbf{T W h}]\end{array}$ \\
\hline 2020 & 203664 & 8389 & 94,00 & 788 & 0.158 \\
\hline 2025 & 226792 & 8396 & 3637 & 30359 & 6.11 \\
\hline 2030 & 249921 & 8627 & 24962 & 215356 & 43.07 \\
\hline 2035 & 273050 & 9052 & 30044 & 271960 & 54.40 \\
\hline 2040 & 296179 & 9637 & 30729 & 296149 & 59.23 \\
\hline
\end{tabular}

The obtained energy demand of $3.08 \mathrm{TWh}$ in 2024 is similar to the estimated demand in 2025 by the Ministry of Energy [4]. The demand is expected to grow 
significantly in the coming years. Ultimately, by 2040 , the demand for electricity needed to recharge electric cars will have stabilised at the level of about $60 \mathrm{TWh}$ per year, which accounts for about $37 \%$ of the current domestic energy demand. This is a significant figure which requires modernisation and construction of new generation sources.

\section{Forecast of growth in demand for power in Polish NPS}

In order to estimate the impact of electric cars on the power/load curve, the load profile of the charging stations should be determined. Charging stations can be divided into two categories: fast and slow charges. Slow charging makes more efficient use of energy and has a less damaging effect on the energy storages used in electric cars. From the point of view of NPS, this charging method is also more advantageous, as it leads to an equalisation of the demand curve. To ensure this, two conditions should be met: a favourable energy price at times of low consumption and the possibility of storing sufficient energy to cover the entire 24hour route of the vehicle. With such assumptions it is said that loading could take place during the hours when the traffic is the lowest, i.e. at night. An example of the flow of the traffic in particular hours of the day for different days of the week is presented in [15]. Based on this traffic profile, a car loading profile was created, as shown in Fig. 1.

The load profile for the week, in which the peak power demand occurred in 2017, was assumed (January 9 to 15) for the forecast of the increase in demand for power [16]. The maximum load of $26046 \mathrm{MW}$ occurred on Monday, January 9. On the basis of the forecasted increase in energy demand, the additional average load $\left(P_{\text {av.add }}\right)$ obtained from the need to recharge electric passenger cars has been determined by formula (8):

$$
P_{\text {av.add }}=A / 8760, \text { in MW. }
$$

Additional load was determined by multiplying the coefficients assumed in the profile (Fig. 1) by the average power $\left(P_{\mathrm{av}}\right)$. Average forecast was made for 2026 and 2030, while in previous years the forecasted increase in demand of power was negligible, and in later years the forecasted demand did not change significantly. The power demand profile obtained is shown in Fig. 2.

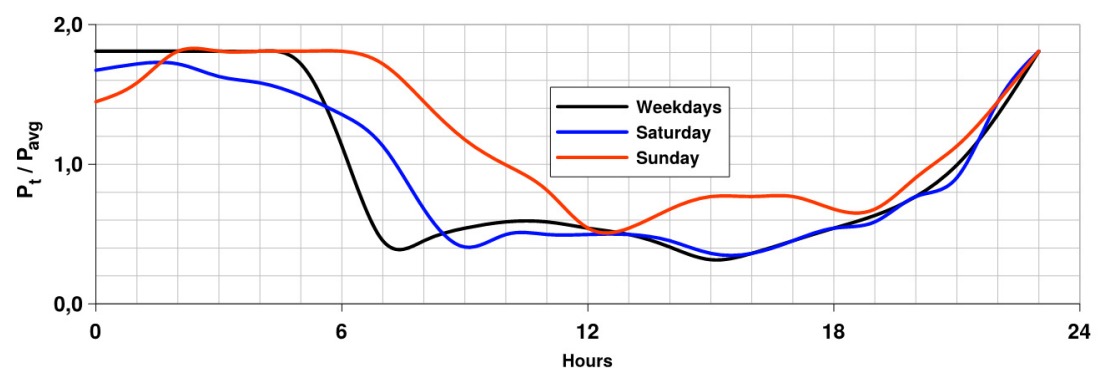

Fig. 1. Adopted load profile (ratio of instantaneous power to average power) for charging. 


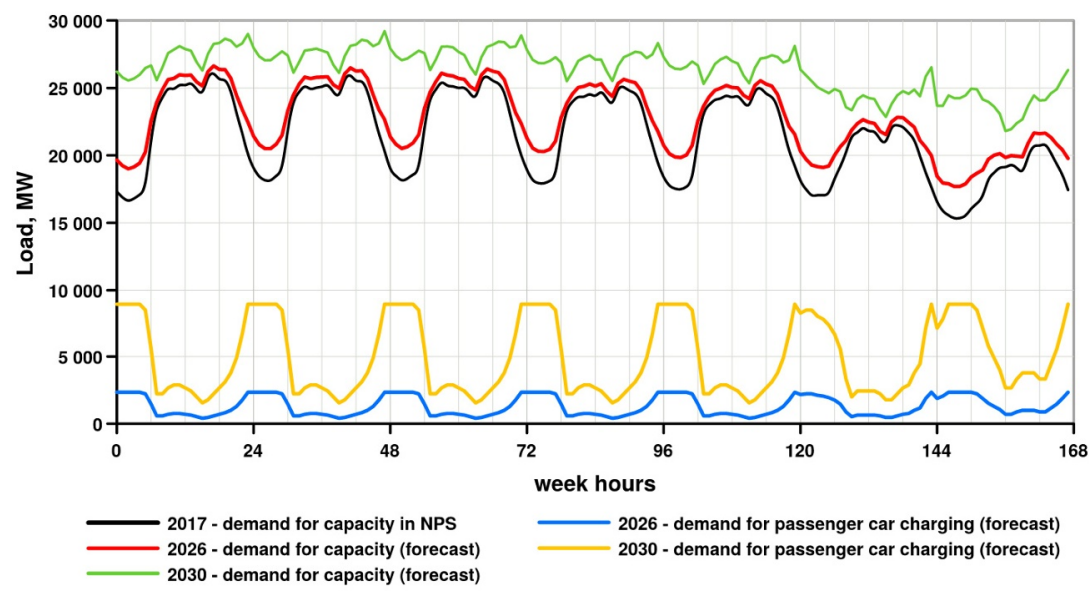

Fig. 2. Projected additional power demand from passenger car charging and the demand for power in NPS in 2026 and 2030.

The projected maximum load levels $\left(P_{\max }\right)$, the average weekly load $\left(P_{a v}\right)$, the average at peak load day $\left(P_{a v, p e a k}\right)$ and minimum load $\left(P_{\min }\right)$ in the peak week for 2024, 2026, 2028 and 2030 are shown in Table 3. The daily power demand curve will change as the number of electric cars increases. The night demand valley will be gradually filled up, which is beneficial from the point of view of the power system. However, it should be remembered that the condition for such a change is the benefit of the use of chargers at night and the complete elimination of charging during the day.

Table 3. Projected maximum load levels, averages per week, average peak load day, minimum load and peak load demand for years 2024, 2026, 2028, and 2030.

\begin{tabular}{|c|c|c|c|c|c|}
\hline Year $\boldsymbol{t}$ & $\boldsymbol{P}_{\boldsymbol{m a x}}[\mathbf{M W}]$ & $\boldsymbol{P}_{\boldsymbol{a v}}[\mathbf{M W}]$ & $\boldsymbol{P}_{\boldsymbol{a v}, \text { peak }}[\mathbf{M W}]$ & $\boldsymbol{P}_{\boldsymbol{m i n}}[\mathbf{M W}]$ & $\boldsymbol{A}_{\text {tpeak }}[\mathbf{T W h}]$ \\
\hline 2017 & 26046 & 21500 & 22475 & 15350 & 3.612 \\
\hline 2024 & 26205 & 21851 & 22814 & 15985 & 3.671 \\
\hline 2026 & 26633 & 22797 & 23729 & 17697 & 3.830 \\
\hline 2028 & 27583 & 24728 & 25595 & 20896 & 4.154 \\
\hline 2030 & 29209 & 26416 & 27227 & 21813 & 4.438 \\
\hline
\end{tabular}

With the assumed charging profile, despite a significant increase in energy demand, the projected increase in peak load demand is relatively small, as it is at the expense of night demand valley's and will reach approximately $3100 \mathrm{MW}$. However, this is an optimistic option as the charging profile depends on the preferences of electric car users. If cars are charged during the day, an increase in load could jeopardise the operational safety of the NPS. The forecast does not include the growth in general load and the change in profile resulting from other factors. 


\section{Impact of the EVCS infrastructure operation on the distribution grid}

\subsection{Considered area}

The key activity in the construction of the distribution network model is the technical and social definition of the representative area where the operation of the power system was analysed. The area of the commune with a population of about 40 thousand people was proposed for the study. It was assumed that the commune is located in the Mazowieckie Voivodeship, near a large urban agglomeration. This assumption is important in order to characterise the lifestyle of the inhabitants, which has been turned into the functioning of the power grid, as well as the designed and located infrastructure for charging electric vehicles. It was also assumed that there is no public transport in the commune, but it has a good railway connection with a large urban agglomeration. Near the railway and bus station, there is a parking lot called Park \& Ride. The commune is located at the crossroads of two road transit routes, which means that during the day, especially during rush hour, there is a high intensity of car traffic leading to congestion in the city and on the exit roads. Moreover, the points of working time of the analysed network, corresponding to different day periods, were defined. For instance, on weekdays there are three periods: working hours (Work), rush hours in the morning and in the afternoon, night hours. A different division is proposed for weekends and holidays, where the day is divided into two periods - day and night. A special period of afternoon rush hours, on weekdays, is the so-called " $\mathrm{X}$ " season. During this moment of the day, the occurrence of extremely unfavourable operating conditions of the power system was simulated. The " $\mathrm{X}$ " scenario assumes the functioning of the system with air temperatures exceeding $25^{\circ} \mathrm{C}$ and increased demand for power both at households and in industrial plants [17-18].

\subsection{Scenarios for developing electromobility}

Three scenarios for the development of electromobility were prepared for the study: a conservative scenario, a moderate scenario and an aggressive scenario [1718]. The total number of electric vehicles in the commune was determined on the basis of data prepared by the Institute of Environmental Protection as part of the implementation of the project "Energy efficiency through the development of electromobility in Poland". Analysing the individual scenarios, the situation at the beginning of the project (2017) with zero number of electric vehicles in the commune was assumed. It should be noted that a theoretical estimation of the number of EVCS charging points, based solely on the total number of vehicles, is not sufficiently accurate and does not reflect the nature and charging behaviour of different types of electric vehicles. To illustrate the differences, the vehicles are divided into three segments: passenger cars, buses, trucks [11]. A detailed division is given in Table 4.

Each of those three scenarios had different characteristics. For instance, in conservative scenario incentives to buy and use EV were not prepared and 
therefore the EVCS infrastructure was developed because of the expectations of the inhabitants who decided to buy EV towards the local authorities. On contrary in both moderate and aggressive scenario incentives to encourage residents to buy an EV were introduced. The main difference between those two scenarios is intensity of development of EVCS. In the aggressive scenario, not only the municipal authorities took part in development process, but also national authorities as well as DSOs and EV and EVCS producers. The result was creating EVCS infrastructure in such way that its availability and friendliness encourage the inhabitants to use EV. In order to define the approximate number of charging points, it was necessary to determine the potential maximum number of vehicles to be charged for a given scenario. These figures were estimated on the basis of an analysis of the inhabitants' lifestyles and the definition of a profile of potential EV users. The total number of charging points in individual scenarios and years is shown in Figure 3 [17].

Table 4. Comparison of electric vehicles number in the analysed scenarios.

\begin{tabular}{|c|c|c|c|c|c|c|c|c|c|}
\hline \multirow{2}{*}{$\begin{array}{c}\text { Type of } \\
\text { vehicle }\end{array}$} & \multicolumn{3}{|c|}{ Conservative scenario } & \multicolumn{3}{c|}{ Moderate scenario } & \multicolumn{3}{c|}{ Aggressive scenario } \\
\cline { 2 - 10 } & $\mathbf{2 0 2 0}$ & $\mathbf{2 0 2 5}$ & $\mathbf{2 0 3 0}$ & $\mathbf{2 0 2 0}$ & $\mathbf{2 0 2 5}$ & $\mathbf{2 0 3 0}$ & $\mathbf{2 0 2 0}$ & $\mathbf{2 0 2 5}$ & $\mathbf{2 0 3 0}$ \\
\hline Cars & 17 & 129 & 350 & 53 & 410 & 800 & 136 & 693 & 1150 \\
\hline Buses & 10 & 30 & 40 & 8 & 25 & 40 & 5 & 20 & 45 \\
\hline Trucks & 1 & 40 & 66 & 2 & 49 & 112 & 2 & 57 & 162 \\
\hline Total & $\mathbf{2 8}$ & $\mathbf{1 9 9}$ & $\mathbf{4 5 6}$ & $\mathbf{6 3}$ & $\mathbf{4 8 4}$ & $\mathbf{9 5 2}$ & $\mathbf{1 4 3}$ & $\mathbf{7 7 0}$ & $\mathbf{1 3 5 7}$ \\
\hline
\end{tabular}

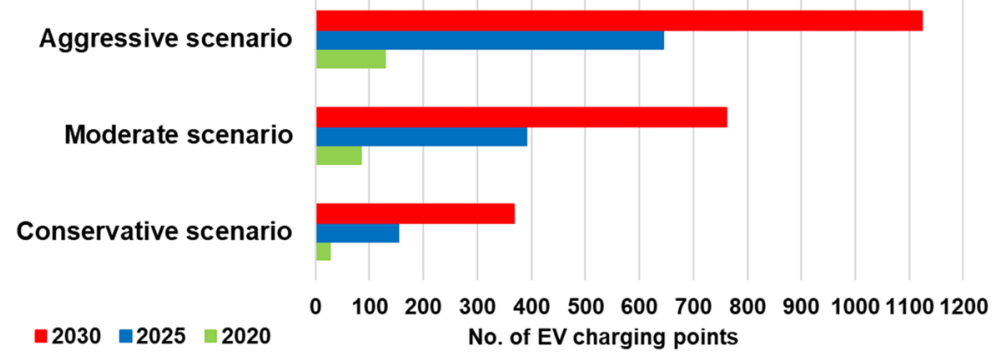

Fig. 3. Number of chargers to work with the assumed number of electric vehicles for all scenarios.

The type of EVCS station, at specified place, was selected to meet the needs of the vehicles being charged and the users' expectations (e.g. fast charging devices for passenger cars and also for electric trucks were installed at service stations). Therefore, the power range of the charging devices ranged from several kilowatts (home chargers) to several hundred kilowatts (fast chargers for passenger cars and chargers for buses and trucks [17-19]).

\subsection{Model and methodology for technical adequacy analysis}

The distribution network model was prepared on the basis of an analysis of typical structures and topologies currently operating in Poland. The modelled distribution network is built in a radial system. It is supplied with power from one distribution substation with two 40 MVA transformers. In the urbanised area of the commune, 
the connections between the network nodes are made by means of cable lines, and in rural areas by overhead lines. It was also assumed that the development of the power grid in the analysed commune was conducted simultaneously with the growing needs resulting from the development of the commune, as part of the electrification process. In order to diversify the load profile within end users, many types of electricity supply points have been modelled for the purpose of the study. With that being said, the model distinguishes following groups of end users such as: residential ones (single-family houses, housing estates), offices, industrial plants, service facilities (shops, petrol stations, bus station, hotel), warehouses and schools. [17-19].

The analyses were aimed at diagnosing potential changes and stress events in the several areas of technical operation of the distribution network including: daily load profile (as well as reactive power demand), load levels of transformers and power lines, the possibility of voltage drops in the distribution network, potential increase in the level of harmonics, and impact of distributed generation (DG) on daily operation of analysed network, while taking into account the functioning of EVCS.

\subsection{Analysis of the technical adequacy of the modelled distribution network while taking into account the EVCS}

Regardless of the strategy, it was found that the most frequently installed type of EVCS was the public charger, with a charging capacity ranging from $11 \mathrm{~kW}$ to 22 $\mathrm{kW}$ - a bar station at home, in offices and in public places. The number of charging stations for trucks and buses depends on the type of incentive given to businesses and the plans for developing electric public transport. On the basis of the conducted analyses [17-19], potential threats to the operation of the distribution network were found, assuming dynamic development of the electric car fleet in the local area. One of the most significant issue, pointed out during the analyses, was increase in load on existing distribution elements, especially on transformers. With that being said the most common overloads occur during daytime hours at weekends and are due to the fact that EVCS mainly charges transformers supplying residential buildings during this period. However, analyses showed that overloading of power lines is not the issue, mainly because they are oversized. The next key problem that was indicated during analyses is change and increase in daily load profile of local commune. It is believed that number of EVCS influence on increase in both active and reactive power demand. Also regardless of the scenario, the peak and low demand times are the same as in the same periods, as they are due to the behaviour of the customers and the profile of the electric vehicle users. An example of a daily load curve for year 2030 is shown in Fig.4. 


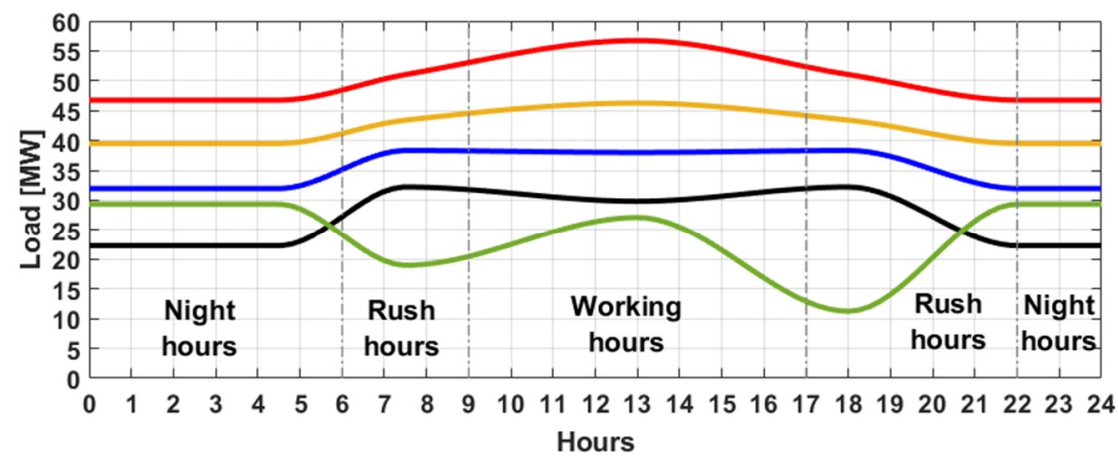

Fig. 4. Example of a daily load profile of a $110 \mathrm{kV} / 15 \mathrm{kV}$ substation for a typical weekday in 2030 (black - current load profile; blue - Conservative scenario; yellow - moderate scenario; red aggressive scenario; green - moderate scenario with DG).

Finally, analyses showed significant impact of the EVCS infrastructure on the quality of electricity, including: increased voltage drops in the distribution network and increased voltage deformations resulting from an increase in the number of non-linear and quasi-linear loads connected to the NPS at the level of the medium voltage network.

\section{Conclusions}

The development and popularisation of the electric cars are slowly becoming a reality. Electric cars are currently being deployed to the market. Experience with other products constituting technological innovation suggests that the development of electromobility will be dynamic in a few years' time. This depends on many factors: technical, legal, economic or marketing (whether there will be a fashion for electric cars). It can be assumed that within 15-20 years electric cars may constitute the majority of vehicles on Polish roads. Additional demand for power and a significant increase in demand for electricity are the problems faced by NPS. The development of electromobility should be taken into account in the planning of the development of the power system, both at the level of the generation subsystem and of the transmission and distribution subsystems. The impact of electromobility on the system will mainly depend on the evolution of the load curves associated with car charging. Charging EV's during night time should be promoted as far as possible at the expense of discouraging fast charging during the day by an appropriate economic, legal and technical environment. In the case of night-time charging, despite a significant increase in energy demand, the demand for power will increase to a much lesser extent, which will allow to maintain the safety of NPS operation. If charging is not promoted during night-time load drop hours, the significant additional power demand may be a challenge that the current national power system will not be able to withstand.

The preparation of scenarios for the development of electric vehicle charging infrastructure, taking into account national electromobility development plans, the simulations of the operation of the distribution network, including the location and operation profile of electric vehicle charging stations for the scenarios developed, and the analysis of the obtained results allowed the formulation of general 
conclusions as to the possibilities for the development of electromobility in Poland [17-19]. Firstly the preparation of long-term plans for the development of the EVCS infrastructure will enable the DSOs to prepare an appropriate strategy for the modernisation of the distribution network which might include completely new approach to this particular problem. Every modernisation of the grid should force the introduction of advanced diagnostic and measurement equipment (including advanced data acquisition and telecommunications systems) which could be used in purpose of enabling V2G (Vehicle to Grid) technology and creating intelligent grid, so called SMART GRID. Secondly EVCS infrastructure will have a major impact on NPS, as number of charging stations will increase in subsequent years. Results showed that not only covering extra load will be an issue, but also maintaining high standards of the quality of electric energy. To compensate potential missing capacity effect, DSOs with the support of local and national authorities should develop distribution generation (DG), which includes installing energy storage systems. At last, representatives of local and regional authorities must be actively involved in the process of creating an EVCS infrastructure for a given area. Their knowledge of the region and the behaviour and needs of the inhabitants is important for the proper adaptation of the charging infrastructure design to the needs of potential EV users.

The article is based on partial reports from the tasks carried out by the Institute of Electrical Power Engineering of Warsaw University of Technology under the project "Energy Efficiency through the Development of Electromobility in Poland" co-financed from the Norwegian Financial Mechanism 2009-2014 under the Bilateral Cooperation Fund. The project was carried out in cooperation with the Institute of Environmental Protection NIB, Institute of Applied Research of Warsaw University of Technology, Faculty of Electrical Engineering of Częstochowa University of Technology and Norwegian partner Green Business Norway. The project also included technical adequacy analyses of the transmission system and the NPS generation sub-sector.

\section{References}

1. Dyrektywa parlamentu europejskiego i rady 2009/72/WE z dnia 13 lipca 2009 r. dotyczaca wspólnych zasad rynku wewnętrznego energii elektrycznej i uchylajaca dyrektywę 2003/54/WE

2. Dyrektywa parlamentu europejskiego i rady 2014/94/UE. z dnia 22 października 2014 r. $w$ sprawie rozwoju infrastruktury paliw alternatywnych

3. Ustawa z dnia 11 stycznia 2018 r. o elektromobilności i paliwach alternatywnych

4. Ministerstwo Energii: Plan Rozwoju Elektromobilności w Polsce, Energia dla przyszłości (Warszawa 2016)

5. J. Purczyński, K. Bednarz-Okrzyńska: Wybrane metody estymacji parametrów funkcji logistycznej. Studia i Prace WNEiZ US. 45/2 (2016)

6. J. Żurowska: Zastosowanie modelu trendu logistycznego do prognozowania wskaźnika motoryzacji w Polsce, Archiwum motoryzacji, 2 (2007)

7. G. Gierszewska, M. Romanowska: Analiza strategiczna przedsiębiorstwa, Polskie Wydawnictwo Ekonomiczne (Warszawa 2009)

8. J. W. Zartha: Application of the Technology Life Cycle and S-Curves to the "Brain Drain" Area of Knowledge, Indian Journal of Science and Technology (November 2017) 
9. Główny Urząd Statystyczny: Prognoza ludności na lata 2014-2050 (opracowana w 2014 r.) (Warszawa 2014)

10. Główny Urząd Statystyczny: Mały Rocznik Statystyczny Polski 2017 (Warszawa 2017)

11. Główny Urząd Statystyczny: Transport drogowy w Polsce w latach 2014 i 2015 (Warszawa 2017)

12. Główny Urząd Statystyczny: Transport- wyniki działalności w 2016 r, (Warszawa 2017)

13. W. Moćko, M. Ornowski, Szymańska M.: Badanie zużycia energii przez samochód elektryczny w czasie testów drogowych, Zeszyty Problemowe - Maszyny Elektryczne, $2 / 2013$

14. H. Pikosz, B. Ohde, G. Ślaski: Modelowanie energochłonności eksploatacji samochodu elektrycznego $w$ warunkach ruchu miejskiego dla potrzeb symulacji zużycia energii przez flotę taksówek, Logistyka, 4 (2014)

15. A. Olma: Coefficients of traffic density fluctuations on the urban roads network, Architecture Civil Engineering Environment, (2009)

16. Polskie Sieci Elektroenergetyczne: Dane historyczne o poziomie zapotrzebowania mocy KSE, [online]: https://www.pse.pl/

17. M. Kłos, Ł. Rosłaniec, R. Bielas, M. Błędzińska, J. Paska, K. Zagrajek, K. Wróblewski: Analizy rozplywowe systemu elektroenergetycznego uwzględniajace scenariusze ilościowe i obszarowe wprowadzania na szeroka skale floty samochodów elektrycznych do Polski Podsektor dystrybucyjny KSE, IEn PW (Warszawa 2017)

18. Ł. Rosłaniec, Ł. Michalski, K. Zagrajek, K. Wróblewski: Analizy rozplywowe systemu elektroenergetycznego uwzględniajace scenariusze ilościowe $i$ obszarowe wprowadzania na szeroka skale floty samochodów elektrycznych do Polski, IBS PW (Warszawa 2017)

19. D. Baczyński, P. Helt, P. Piotrowski, D. Pyza, S. Robak, P. Kapler, T. Wójtowicz: Ocena poziomu potencjalnych zaktóceń mogących negatywnie wptynać na sieć elektroenergetyczna na poziomie niskiego napięcia zwiazanych z zaprojektowana infrastruktura ładowania samochodów elektrycznych $w$ wybranych lokalizacjach. Analiza wybranych aspektów ekonomicznych, IEn PW, (Warszawa 2017) 